\title{
CHILD CASH BENEFITS AND FAMILY EXPENDITURES: EVIDENCE FROM THE NATIONAL CHILD BENEFIT
}

\author{
Lauren E. Jones \\ Kevin S. Milligan \\ Mark Stabile \\ Working Paper 21101 \\ http://www.nber.org/papers/w21101 \\ NATIONAL BUREAU OF ECONOMIC RESEARCH \\ 1050 Massachusetts Avenue \\ Cambridge, MA 02138 \\ April 2015
}

The views expressed herein are those of the authors and do not necessarily reflect the views of the National Bureau of Economic Research.

At least one co-author has disclosed a financial relationship of potential relevance for this research. Further information is available online at http://www.nber.org/papers/w21101.ack

NBER working papers are circulated for discussion and comment purposes. They have not been peerreviewed or been subject to the review by the NBER Board of Directors that accompanies official NBER publications.

(C) 2015 by Lauren E. Jones, Kevin S. Milligan, and Mark Stabile. All rights reserved. Short sections of text, not to exceed two paragraphs, may be quoted without explicit permission provided that full credit, including $(\mathcal{C}$ notice, is given to the source. 
Child Cash Benefits and Family Expenditures: Evidence from the National Child Benefit

Lauren E. Jones, Kevin S. Milligan, and Mark Stabile

NBER Working Paper No. 21101

April 2015

JEL No. H51,H53,J18

\begin{abstract}
$\underline{\text { ABSTRACT }}$
A vast literature has examined the impact of family income on the health and development outcomes of children. Income may improve child outcomes through two mechanisms. First, income may improve development outcomes if it improves a family's ability to purchase direct inputs into child education and health production such as reading material, educational equipment, and health care. Second, by reducing stress and conflict, additional income helps to foster an environment more conducive to healthy child development, regardless of the nature of specific expenditures. In this paper, we exploit changes in refundable tax benefit income in Canada to study these questions. Importantly, our approach allows us to make stronger causal inferences than has been possible in existing studies. Using variation in child benefits across province, time, and family type, we study expenditure patterns of families receiving child benefits. Our findings suggest that additional income may improve outcomes through both mechanisms: some benefit income is spent on direct education and health inputs, while some is spent on everyday items likely to improve the general conditions children face. Additionally, some families reduce spending on risky behavior items. Spending responses to benefit generosity appear to vary by income.
\end{abstract}

Lauren E. Jones

University of Toronto

lauren.jones@rotman.utoronto.ca

Kevin S. Milligan

Vancouver School of Economics

University of British Columbia

\#997-1873 East Mall

Vancouver, BC V6T 1Z1

CANADA

and NBER

kevin.milligan@ubc.ca
Mark Stabile

University of Toronto

14 Queen's Park Cres. W.

Toronto, ON M5S 3K9

CANADA

and NBER

mark.stabile@utoronto.ca 


\section{Introduction:}

Programs designed to transfer income to low-income families are common in many jurisdictions. The Earned Income Tax Credit in the United States, the Working and Child Tax Credits in the UK, and the National Child Benefit and Working Income Tax Benefits in Canada are examples of such programs. Each of these programs provides cash transfers that can be spent at the discretion of the recipient, and they tend to be either exclusively available to families with children or more generous for such families. While such programs often have multiple goals, one common policy aim is to improve the lives and chances of children in these families, and to lift them out of poverty. A number of recent papers have investigated how successful such programs are in achieving this goal. Dahl and Lochner (2012) and Milligan and Stabile (2011) both find, for example, that these programs lead to improved outcomes for children, both in terms of math and reading skills, and in terms of mental and physical health measures. One question that remains unanswered is how transfer programs achieve these results.

The programs and credits mentioned above transfer income unconditionally to expand the budget set of qualifying families. There are two mechanisms through which transfers might theoretically improve the lives of children. On the one hand, families may simply use the income to purchase more goods and services, including those goods that are valuable in improving education and health outcomes. If families use additional income to purchase direct inputs to education or health, such 
as tuition, reading materials, health care or nutritious food, improvements in these areas are likely to occur. Previous research has labeled this the "resources channel" (Mayer 1997, and Yeung et al. 2002).

On the other hand, income transfers may improve health and education outcomes indirectly if additional income reduces stress and improves household relations, increases the chance and opportunities for employment, and others. Spending in areas like housing, recreation, food or clothing, for example, may improve general health and education indirectly by improving the conditions children face in their ability to function, learn, and improve themselves. Yeung et al. (2002) have labeled this channel the "family process channel". Recent research (Currie and Stabile, 2009; Currie, Stabile, Manivong and Roos, 2008) has documented a strong relationship between early child mental health and both shortterm educational achievement and longer-term economic outcomes such as welfare take-up. As such, the possibility that a broader set of expenditures, not necessarily immediately related to education, might also improve future educational outcomes is quite plausible.

This paper builds on previous research that identifies the positive relationship between child education and health outcomes and child benefit programs by examining in detail how exactly families spend benefit income. Using data from twelve years of Canadian expenditure surveys, we exploit considerable variation across time, region and family size to identify the marginal effect of an extra dollar of benefit income on spending in many categories. The nature of the 
benefit program in Canada allows us to estimate the relationship between benefits and spending for families over a wide range of incomes, as well as for low-income, benefit-eligible families. The exogenous policy variation in child benefits across time, space and family size also allows us to provide plausible causal estimates of the effect of benefit income on expenditures.

In addition to the advantages in identification, the Canadian expenditure data offer several advantages, including a broad range of spending categories, accurate reporting and auditing of expenses, and reliable geo-codes for all respondents. ${ }^{1}$ The findings provide considerable support for both the "resources channel" and the "family process channel" defined above, including several refined and novel findings. Among families with incomes below the $25^{\text {th }}$ percentile in our sample we find evidence of increases in spending on education, including on tuition and computer supplies. We also find evidence that families spend benefit income on basic household needs such as food, transportation and child care. Among the full sample we find large decreases in alcohol and tobacco consumption with an increase in child benefits.

The rest of the paper proceeds as follows: section II reviews previous work on both the relationship between child benefits and outcomes as well as evidence on how families spend unconditional cash transfers and tax refunds. Section III reviews the policy environment and variation explored in this research. Section IV presents

\footnotetext{
${ }^{1}$ This is in comparison to the US Survey of Consumer Expenditures (CEX), whose lack of state codes prohibits the use of state-by-state variation in benefit generosity as an instrument.
} 
the data, methods and identification strategy. Section V presents our results and section VI concludes.

\section{Previous Work}

Two strands of literature inform our current study: work examining the relationship between child benefits and child outcomes, and work exploring how families spend benefit income. There is an extensive body of work looking at the relationship between child benefits and child outcomes. Perhaps most relevant to this study are the more recent studies that look explicitly at the benefits of spending through the National Child Benefit in Canada (Milligan and Stabile 2009, 2011) and through the EITC in the United States (Dahl and Lochner, 2012, Michelmore, 2013; Hoynes, Miller and Simon 2015). Each of these papers finds a positive relationship between cash transfers to low income families and child outcomes. In the Canadian context, Milligan and Stabile find positive effects on test scores, mental health and some physical health. In the US context, Dahl and Lochner find positive effects of EITC receipt on child math and reading scores. Michelmore finds positive effects of the EITC on college enrollment and receipt of a bachelor's degree, while Hoynes and coauthors find that increased EITC generosity reduces the incidence of low birth weight. While our work does not explicitly look at child outcomes, it builds directly on our previous work using the Canadian National Child Benefit by exploring the causal mechanisms at play (as in Mayer (1997) and Yeung et al. (2002), among others) in generating these positive outcomes. 
The second area of research relevant to our study explores how families spend benefits, both anticipated and unanticipated. Empirical studies have used income tax returns and tax rebates, which provide more or less expected payments, to gauge how spending behavior is impacted by such anticipated income shocks. In general, these studies find high sensitivity of household consumption to tax refunds, meaning that families are prompted to increase spending after the income shock. (Souleles 1999; Shapiro \& Slemrod 2003; Johnson, Parker \& Souleles 2006; Agarwal, Liu \& Souleles 2007; Cole, Thompson \& Tufano 2008; Bertrand \& Morse 2009; Shapiro \& Slemrod 2009; Baugh, Ben-David \& Park 2014). The proportion of the return or rebate spent on nondurable goods-spending which does not directly build wealth—has been found to depend on individuals' access to credit. More credit constrained people tend to spend their tax rebate income more quickly (or are less likely to save it or use it to pay down debt), and are more likely to spend it on nondurable necessities like gas or groceries (Cole, Thompson \& Tufano 2008; Agarwal, Liu \& Souleles 2007; Bertrand \& Morse 2009). In many of these studies, timing is the main source of variation: benefits come in lump sums at different times of the year, instead of a more predictable monthly payout for all families. Also, while many of the studies do look at credit-constrained individuals, the focus of most of this work is not on the poorest families, who tend to receive the largest amount of unconditional child benefit.

A number of papers have also explored how families spend EITC benefits. These papers are especially information for our work, since the EITC benefits a population comparable to those who receive the bulk of the National Child Benefit 
explored herein. In general these papers compare spending patterns among families eligible for the benefit to those among the ineligible over the months when the benefit income is received (most EITC recipients, for example, receive a lump sum payment in February or March). Barrow and McGranahan (2000) use consumer expenditure data to examine whether EITC credits change seasonal expenditures for low income workers. They find that EITC eligible workers increase expenditure by around 3 percent in the month EITC is received and that the benefit facilitates the purchase of large expenditures in particular. McGranahan and Schanzenbach (2013) also exploit the fact that EITC benefits are not paid out evenly over the calendar year to compare EITC eligible households to non-EITC eligible households and find increases in basic consumption items such as fresh food in those months where the benefits are paid (plausibly related to increases in health among EITC families). Goodman-Bacon and McGranahan (2008) use a similar identification strategy of comparing EITC-eligible families to those not eligible to look more specifically at individual spending categories (as we do in this paper) and find increases non-durables such as children's clothing and transportation as well as durables such as vehicle purchases.

Research by Waldfogel and Washbrook (2005) examining the expansion of a number of benefit programs in the UK uses a difference-in-differences approach to compare spending patterns among low-income families versus higher income families before and after the 1999 expansions. These expansions targeted lowincome families and were most generous for those with children under the age of 10 . They find that low income families that should have benefited from the expansions 
had consumption patterns post-expansion that more closely resembled those of higher income families and that spending on child-related items increased faster than spending on other items.

Our research aims to add to this literature in a number of ways. First, we use exogenous variation within benefit-eligible families to estimate the effect of an additional dollar of benefit within the low-income population. This approach offers advantages over other papers that compare spending trends over the course of the year among the benefit-eligible population to those among higher income families. Second, we are able to directly impute the benefits received by each household using detailed data on income to determine benefit eligibility and are able to verify these imputations against reported benefit receipts. Third, the Canadian context offers a payment structure that is spread out over the year (paid monthly) and predictable, in contrast to the lump sum payments examined in the US context. Recent work by Yang (2014) shows that EITC lump sum payments have an immediate impact on labour supply when received (in February) and almost no impact on labour supply later in the year. This suggests that payment timing is potentially an important issue and that responses may be very different to a benefit with monthly payment such as those paid by the NCB. Finally, we benefit from access to a large, cross-sectional data set of many families, available for a long timespan covering benefit expansions. Moreover, because we have previously observed a plausibly causal relationship between receipt of these benefits and improved child health and educational outcomes over the same time-span, the current work can help open up the 'black box' between the increase in benefits and the observed 
health and education improvements (Milligan and Stabile 2009, 2011). The data used here, the Survey of Household Spending, (SHS) is recognized as having many advantages over the Consumer Expenditure Survey including having a balance edit to ensure accuracy (Carroll et al. 2014), having complete and accurate region of residence data, and having superior aggregate coverage rates and larger sample sizes (Barrett et al. 2014). Further details on the SHS are provided in our data section below.

\section{Child Benefits in Canada²:}

In Canada, there are a variety of child benefits delivered through the tax system in different ways. In this section, we describe the principle components of the system, starting with the federal policies and ending with the provincial measures.

The backbone of the system is the Canada Child Tax Benefit (CCTB), which in 1993 took its current form as a refundable tax credit paid monthly to families with children age 0 to 17 . The payment rates of up to $\$ 1446$ (for 2014-15; indexed to inflation) annually per child are uniform across the country, with two provincial exceptions. $^{3} \mathrm{~A}$ small supplement of $\$ 101$ per year is paid for families with three or more children. When family net income exceeds $\$ 43,953$, ССТВ payments are phased out at a rate of 2 percent for one-child families and 4 percent for those with

\footnotetext{
${ }^{2}$ This section draws heavily on Milligan and Stabile (2011).

${ }^{3}$ In Alberta, the benefit is differentiated by age of the child. For example, in 2014 children age zero to six received $\$ 1,333$ while those age 16 to 17 received $\$ 1,687$. Until 1997, benefits paid to Quebec residents depended on how many children were in the family, with higher-order children receiving more benefits. We account for each of these exceptions in our benefit calculator.
} 
2 or more children. Payments are paid out on a July to June 12-month schedule, based on the tax filing for the previous calendar year. So, the July 2014 to June 2015 CCTB payment was based on reported family net income from 2013.

A substantial benefit was added in 1998 aimed at parents making the transition from social assistance (welfare programs for those not working) into the workforce. The National Child Benefit program is a federal-provincial initiative featuring a federally-paid benefit called the National Child Benefit Supplement (NCBS). Benefit amounts were initially around $\$ 500$ annually per child, but are now around $\$ 2,000$ per child. These benefits are phased out based on net family income in the previous year, as with the ССТВ, and are paid monthly from July to June. 4 Many provinces chose to reduce the social assistance payments they were already making to out-of-work parents dollar-for-dollar with the new NCBS. Provinces then used these 'savings' to fund initiatives for children in their provinces. Quebec did not participate in the National Child Benefit system, but introduced major reforms to its child benefits system in 1997, and then again in 2005.

Two new benefits were added in 2006 and 2007. In 2006, the Universal Child Care Benefit of $\$ 100$ per month per child under age 6 was added. This benefit was paid to the lower income spouse, and taxed as income. The Working Income Tax Benefit was added to the mix in 2007, providing a benefit to supplement earned income. This benefit is embedded in the annual tax form rather than paid through

\footnotetext{
${ }^{4}$ In 2014-15, the phaseout threshold is $\$ 25,584$ and the rates are set such that the benefit has been completely phased out by $\$ 43,953$. The benefit amounts for $2014-15$ are $\$ 2,241$ for the first child, $\$ 1,981$ for the second, and $\$ 1,885$ for the third or higher. Initially in 1998, the benefits were $\$ 605$ for the first child, $\$ 405$ for the second, and $\$ 330$ for the third or higher. Substantial above-inflation increases were put in place in 1999, 2000, 2001, 2003, 2005, and 2006.
} 
monthly payments. Earned income is supplemented by 25 cents on the dollar for earnings over $\$ 3,000$, and then phased out with family net income. From 2007 to 2009 , the benefit was only around $\$ 500$ for singles and $\$ 1,000$ per couple, but these amounts were increased by around $\$ 500$ starting in 2010 . There is no increment for children in this benefit, however.

The final component of the system to consider are provincial benefits. These vary substantially across provinces, but almost all are delivered as a monthly refundable tax credit along with the federal CCTB and NCBS benefits described above. The details of each province's programs are provided in the Appendix. Some provinces have transfers that are paid independent of earnings, while others have earnings-related benefits. Some provinces have both. Provincial differences occur in the amount of the benefit, the income threshold where benefit reductions start, and the reduction rate.

To gather up this information, the policy variation over the past two decades in Canada occurs over several dimensions: year, province, number of children, and income. To explore the extent of this variation, we present several figures. As can be seen, the benefits display substantial heterogeneity across these dimensions.

Figure 1a shows how the amount of total refundable benefit for which a twochild two-parent family from Ontario changes over time. The values come from a tax and benefit calculator. ${ }^{5}$ Importantly, much of the increase comes for those at $\$ 10,000$ and $\$ 25,000$ of income, through the expansion of the National Child Benefit

\footnotetext{
${ }^{5}$ We use the Canadian Tax and Credit Simulator (CTaCS). This is described in Milligan (2015). This is the simulation that will create the instrument we describe below.
} 
program and the associated provincial programs. Figure $1 \mathrm{~b}$ shows how benefits for the same two-child family from Ontario evolve as earnings grow. The large jump between 1994 and 1999 results from the replacement of the $\$ 500$ federal Working Income Supplement with the Ontario Child Care Supplement for Working Families, paying $\$ 1100$ per year. The further increase in 2004 results from the more-than doubling of the federal National Child Benefit Supplement in the first half of the 2000s. ${ }^{6}$ Finally, the increase between 2004 and 2009 is a result of an expansion of the Ontario Child Benefit program, which nearly doubled in 2009.

To explore the extent of provincial variation in benefit amounts, Figure 2 plots the average total refundable benefits among families with children in the Survey of Labour and Income Dynamics. We show how the benefits evolve for families with one, two, and three children. The differences across provinces are large. Quebec follows its own path with a large reform of its own supplemental benefit program in 2005. Newfoundland also shows a distinct pattern for larger families. It is these differences across province, through time, and across family size that we exploit in our empirical strategy described below.

\section{Data and Methodology:}

We are interested in the relationship between benefits and spending, which can be described by the following model:

\footnotetext{
${ }^{6}$ The National Child Benefit Supplement annual rate for two-child families went from \$1,370 in 1999 to $\$ 3,964$ in 2014 .
} 


$$
\operatorname{Spend}_{p y k i}=\alpha_{0}+\boldsymbol{X}_{p y k i} \mathbf{A}_{\mathbf{1}}+\alpha_{2} B e n_{p y k i}+\epsilon_{p y k i}
$$

where $i$ indexes families, and $p, y$ and $k$ index provinces, years and number of children, respectively. Model (1) therefore relates annual spending in category C, for family $i$ to annual benefit income received by family $i$, after controlling for covariates $\mathbf{X}$. The coefficient $\alpha_{2}$ captures the change in spending in category C associated with an additional dollar of benefit income. The estimation of equation (1), however, is complicated by the fact that both benefit income and spending are determined by family income. Since lower income families receive more benefit income while spending less than higher income families, an Ordinary Least Squares estimate of $\alpha_{2}$ will tend to be biased downward.

In previous work on the spending response to benefit and tax refund income, authors have used exogenous variation in the amount or timing of payment of benefits to address the problem of endogeneity in the estimation of model (1) (see, for example, Johnson et al., 2006 or Barrow and McGranahan, 2000). In this spirit, we use a simulated benefits approach that captures policy differences in benefit generosity across provinces, years and number of children (Currie and Gruber 1996; Milligan and Stabile 2011). Our method allows us to overcome the endogeneity of spending to benefit income.

The general idea of the simulated benefits strategy is to produce a measure of benefit generosity that is independent of family-level characteristics, which could affect spending through a path other than the causal one. Using a simple random 
sample of families and the CTaCS tax benefit calculator, we generate tax benefit information for each family. We then move each family through the 520 combinations of province (10), year (13) and number of children (4) and calculate their potential benefits in each scenario. Thus, for each family and associated income profile, we have an estimate of what their benefit would have been had they lived in each potential province-year-number of children world. We average the simulated benefit amounts at the province-year-number of children level. Since each cell is constructed by averaging the hypothetical benefit amounts over the same set of families, the simulated benefit numbers capture the policy variation in benefit generosity but are independent of family-specific characteristics, like income or related unobservables. We use the simulated benefit cells as instruments for the actual benefit amount of each family, given their true province, year and family size characteristics. The two-step procedure starts with estimation of equation (2) as follows:

$B e n_{p y k i}$

$=\beta_{0}+\boldsymbol{X}_{\boldsymbol{p y k i}} \boldsymbol{\beta}_{\mathbf{1}}+\beta_{2} \operatorname{SimBen}_{p y k}+\delta_{p}+\theta_{y}+\lambda_{k}+\mu_{p y}+v_{y k}+\pi_{p k}+\varepsilon_{p y k i}$.

In equation (2), we regress the true benefit amount on the simulated benefit measure, covariates $\mathbf{X}$, as well as province, year and number of children dummies, along with their first-order interactions. We use the predicted benefit values in the second-stage, equation (3): 
SpendC $C_{p y k i}=\gamma_{0}+\boldsymbol{X}_{p y k i} \gamma_{1}+\gamma_{2} B \widehat{n_{l p y k}}+\delta_{p}+\theta_{y}+\lambda_{k}+\mu_{p y}+v_{y k}+\pi_{p k}+\varepsilon_{p y k i}$

The coefficient estimate of $\gamma_{2}$ represents the change in annual spending in category $\mathrm{C}$ associated with an additional dollar of benefit income, where each additional benefit dollar is produced by a change in policy generosity rather than a change in family-specific income. By controlling for province, year, number of children, and their interactions, we are able to isolate the effect of the increased policy generosity within cells; assuming there are no conflicting trends in spending at the province-year-number of children level—a reasonably robust assumptionthen our estimate will reflect the causal effect of increased benefit income on spending in each category.

We use two Statistics Canada survey data sets in our analysis. The first is the Survey of Household Spending (SHS), a nationally representative annual survey of Canadian families intended to measure spending habits. Respondents to the survey are asked to report their spending in the previous year on a wide array of spending categories. ${ }^{7}$ The SHS collects expenditures based on the calendar year through inperson interviews and respondents are encouraged to collect receipts and tax information. A balance edit is used when differences between expenditures, income and savings exceed a 20 percent tolerance level (Barrett et al. 2014). The SHS

\footnotetext{
${ }^{7}$ The SHS is similar to the American Survey of Consumer Expenditure (CEX). However, up until 2010, the Canadian survey did not employ a diary data collection method for smaller purchases, using only the recall method that asks respondents about spending habits over a full year. Further, the SHS does not interview respondents quarterly like the CEX, using instead one response for each household. Additionally, as discussed, the Canadian consumption survey provides reliable province information for all respondents (the CEX suppresses and recodes much of the state information).
} 
includes detailed income data, along with important demographics; however, it does not provide accurate measures of refundable tax benefit income. Thus, we use the CTaCS benefit calculator to impute family benefit income. We use the survey data from years 1997 through 2009, and we restrict our analysis to families with children who live in the ten provinces. We additionally exclude families with total yearly pre-tax income in the top 1 percent, or above about $\$ 250,000$. These restrictions yield a base sample of 59,793. We additionally investigate the relationship between benefits and spending for families with total pre-tax income in the bottom quartile (low-income families, $\mathrm{N}=15,262$ ).

The SHS survey data provides information on an extensive set of spending categories. We choose to focus on categories grouped into four broad areas: education spending; health care spending; stability spending, including expenses like rent, clothing, food, transportation, child care and recreation; and risky spending, including alcohol and tobacco purchases. Our models of spending in the first two areas - education and health- can be thought of as tests of the resource channel hypothesis: spending increase in these areas are direct investments in child outcomes. Models of the stability and risky behavior spending outcomes, by contrast, test for the family process hypothesis: spending in these areas may indirectly improve development outcomes by improving the conditions children face. We also explore the relationships between benefit expenditures and total spending, and spending on non-durable items. ${ }^{8}$ The list of spending categories we

\footnotetext{
${ }^{8} \mathrm{We}$ define non-durable spending to include spending on food, household operations, clothing and personal care, gasoline and parking, public transit, recreation and entertainment, and tobacco and alcohol.
} 
consider, along with their means for the full population and for the low-income population, are displayed in Tables $1 \mathrm{a}$ and $1 \mathrm{~b}$.

We also use 1997-2009 Public Use Microdata Files of the Survey of Labor and Income Dynamics (SLID) to calculate the simulated benefit instrument. The SLID data has the benefit of providing more accurate and detailed income data than the SHS. It also provides reported refundable tax benefit income, which allows us to cross-check the reliability of the benefit imputation process we are required to use in the SHS. To construct the simulated benefit instruments, we use a 10 percent random sample of surveyed families with children. We then rotate this sample through the tax calculator for each province-year-number of children combination, as described above. Averaging at the province-year-number of children level produces the simulated benefit instrument. ${ }^{9}$ We merge the SLID simulated benefit instrument into the SHS data at the province-year-number of children level.

\section{Results:}

We begin by investigating the relationship between our imputed benefits using CTACS in both the SLID and SHS and reported benefit data collected in the SLID. This provides a check on how well the tax calculator captures the benefits families actually receive. The results are reported in Table 2, where we report benefit take up rates and average benefit amounts for the SLID sample (panel A) versus the SHS sample (panel B). We impute that 85 percent of families in the SHS and 80 percent

\footnotetext{
${ }^{9}$ Note that it is entirely possible to produce the simulated benefit instrument using the SHS, and that doing so produces results nearly identical to those reported herein. We choose to use the SLID because of its more reliable income data.
} 
of SLID families in our samples should be receiving benefits. Eighty-one percent of respondent families in the SLID report receiving child benefits, suggesting that our imputation process is highly accurate. Average imputed benefits among receivers in the SLID and SHS are $\$ 2826$ and $\$ 2713$ respectively, while average reported benefits in the SLID are $\$ 2437$. These results are again quite similar.

We estimate the first stage relationship between imputed benefits and the simulated benefits using the Survey of Household Spending data. Our first stage results show a very strong correlation of 0.97 for the full sample and 1.35 for the sample of families with incomes below the $25^{\text {th }}$ percentile. These results are presented in Table 3. For comparison's sake, we estimate the first stage model using an instrument that varies at the province-year level, but is constant across family size. The coefficients decreased in magnitude, but there is still a strong relationship between the simulated instrument and imputed benefits.

We now turn to the results of our analysis of the expenditure outcomes. Estimates of the relationship between benefit income and overall expenditure for both our full sample (panel A) and our sample of households with income below the $25^{\text {th }}$ percentile (panel B) are presented in Table 4. Column (1) reports the OLS estimates for overall expenditure and non-durable expenditure. As we would expect, the OLS estimates of benefit income on expenditure are very large and negative, primarily because families with benefit income are, by definition, lower income and therefore likely to spend less. This result simply highlights the need for an IV approach and we focus on the IV estimates for the remainder of the paper. Column (2) shows the IV results. For the full sample we don't find large overall changes in 
total spending, suggesting that the changes in spending within subcategories cancel each other out and that savings among some families may be increasing. For the low-income sample, however, we large and significant increases in non-durable expenditure with a 0.45 dollar increase in overall consumption per additional dollar of benefit income. Given that the NCB extents up to almost $\$ 100,000$ in income it is reasonable to expect that the bulk of the changes in expenditure would occur for those families in the bottom 25 percentile of the income distribution.

Table 5 reports spending on health and education categories for both our full sample and low-income sample households. These results test the "resource channel" hypothesis: they represent spending changes that should directly impact the health and education outcomes that have been linked to tax benefit programs. We report the response to increased benefits in the probability of spending anything in the particular category (columns (1) and (3)) ${ }^{10}$, and in total spending (columns (2) and (4)).

We find some changes in health care expenditures in the full sample of families. There does not appear to be any increase in overall health care spending, but there is a small increase in eye care spending - both in the probability of spending something on eye care and in the total spent - and an increase in the probability of spending something on prescription drugs. Our largest health care effect is a decrease in dental care spending among both samples. This may be due to the provincial response to the introduction of the NCB. Some provinces used their reinvestment funds to institute universal dental care coverage for children, a fact

\footnotetext{
${ }^{10}$ We did not estimate models on the binary measures of the probability of spending anything for spending categories where most everyone in the sample had some spending, like total health care.
} 
that could explain decreases in family spending in dental care with expansion of child benefit programming. ${ }^{11}$

The pattern for education spending categories is quite different. For the low education subsample we find strong evidence of increases in spending on education categories. We find a significant increase in overall education spending of 0.13 cents, which derives from an increase in spending on tuition (0.06) and on computer supplies (0.06). For the full sample, our estimates of the changes in education spending are positive but smaller and insignificant. It would appear that the bulk of the educational response to increases in child benefits is focused in the lower part of the income distribution.

Table 6 presents results for a set of expenditure items that we classify as "household stability" items. These are items that are not necessarily direct inputs in the production of education and health, but rather are basic expenditure items, the lack of which would contribute to household instability, stress levels, and overall ineffectiveness of the family process (Yeung et al. 2002). Our findings suggest that there are important changes in expenditure among these categories. For example, spending on rent increases by 17 cents per dollar of benefit income for the full sample and 15 cents (although marginally insignificant) for the low-income subsample. Spending on basic food in stores increases by 8 cents for the full sample and 23 cents for the low-income sub-sample, while spending at restaurants decreases for the low-income subsample. Spending on transportation increases by 6.5 cents per dollar for the low-income subsample, and child care spending increases by 6.7

\footnotetext{
${ }^{11}$ The Alberta Child Health Benefit program, for instance.
} 
cents. Recreational spending also increases for the low-income sample with an increase of 12 cents per benefit dollar.

Perhaps the most surprising effects in our expenditure results are for spending in so-called "risky" categories. We find large and significant decreases in both alcohol and tobacco spending among families in the full sample. For the full sample, tobacco expenditures decline by 6 cents per dollar of benefit income and alcohol purchases decline by 7 cents. We additionally find a 3 percentage point decrease (off a base probability of 33 percent) in the likelihood of purchasing any alcohol products in licensed establishments among the low-income sample. These coefficients, presented in Table 7, are among the largest changes in spending that we find in non-major categories.

VI. Discussion and Conclusion:

This paper builds on previous research that identifies the positive outcomes associated with child benefit programs by examining in detail how exactly families use benefit income in order to improve both child health and educational outcomes. Using variation in benefit generosity across years, provinces and family size, we identify changes in total family expenditures and changes in the probability of expenditure across a number of categories. The results contribute to our understanding of how families use benefit income to improve the well-being of their children. Our results reveal some interesting patterns. 
There is evidence that, among low-income families, the benefits are used across a wide variety of expenditure categories, consistent with both the "resource channel" and the "family process channel". We observe direct investments in education, especially for lower income families. There is a clear pattern that some of the resources provided by benefit programs are being used to directly improve learning.

We also uncover evidence in favour of the family process hypothesis. For example, we see increases in purchases of child care, food, rent and transportation (non-durables)—general expenditures required by low-income families. We also see evidence that the benefits may cause families to reorganize their budgets, with less spending on food in restaurants and, especially among the full sample, alcohol and tobacco. These results contradict anecdotal comments that unconditional cash transfers result in increased spending on tobacco and alcohol (see, for example, CBC 2005). It appears that among the population receiving child benefits, the opposite is true.

Our results fit well with several recent papers that show that alcohol and tobacco consumption may be tied to financial hardship. Hoynes et al. (2015) look at the effect of the EITC on infant and maternal health outcomes, and find evidence of a reduction in maternal smoking for women receiving EITC, consistent with our findings. Our finding is also consistent with evidence on the relationship between unemployment and risky behavior where recent evidence shows an increase in maternal smoking with increases in unemployment (Currie et al 2014). A decrease in spending on alcohol and tobacco products is certainly consistent with a decline in 
the overall stress levels in the household as both alcohol and tobacco are often used to relieve stress.

While it is not possible to say for certain how these changes in spending patterns drive improvements in child outcomes, it is likely that benefit income may be helpful in reducing financial stress (and hence reducing consumption of items like alcohol and tobacco) thereby providing an improved learning environment for children. 
References:

Agarwal, Sumit, Liu, Chunlin, Souleles, Nicholas, 2007. "The Reaction of Consumer Spending and Debt to Tax Rebates-Evidence from Consumer Credit Data," Journal of Political Economy, 115(6), pp. 986-1019.

Barrett, Garry, Levell, Peter and Milligan, Kevin, "A Comparison of Micro and Macro Expenditure Measures Across Countries Using Different Survey Methods," in Improving Measure of Consumer Expenditures, Carroll, Christopher, Crossley, Thomas and Shabelhaus, John editors, NBER, 2014.

Barrow, Lisa and McGranahan, Leslie, "The Effects of the Earned Income Tax Credit on the Seasonality of Household Expenditures," National Tax Journal, 53(4) part 2, 2000, pp. 1211- 1244.

Baugh, Brian, Ben-David, Itzhak, and Hoonsuk Park, "Disentangling Financial Contraints, Precautionary Savings, and Myopia: Household Behavior Surrounding Federal Tax Returns," NBER Working Papers \#19783, 2014.

Baughman, Reagan, and Stacy Dickert-Conlin. 2009. "The earned income tax credit and fertility," Journal of Population Economics, 22, pp. 537-563.

Bertrand, Marianne, and Adair Morse, “Trickle Down Consumption," NBER Working Paper \#18883, 2013.

Carroll, Christopher, Crossley, Thomas and Shabelhaus, John, "Introduction to Improving Measurement of Consumer Expenditures," in Improving Measure of Consumer Expenditures, Carroll, Christopher, Crossley, Thomas and Shabelhaus, John editors, NBER, 2014.

CBC News. 2005. "Federal Liberals deride 'beer and popcorn' money". http://www.cbc.ca/archives/categories/politics/elections/fumbles-and-stumbleseight-great-election-gaffes/liberals-deride-beer-and-popcorn-money.html Accessed on. April 2, 2015.

Cole, Shawn, Thompson, John and Peter Tufano, "Where Does it Go? Spending by the Financially Constrained," Harvard Business School Finance Working Paper No. 08083, April 2008. 
Currie, Janet and Mark Stabile. 2009. "Mental Health in Childhood and Human Capital." In The Problems of Disadvantaged Youth: An Economic Perspective, ed. Jonathan Gruber, 149-180. Chicago: University of Chicago Press.

Currie, Janet, Mark Stabile, Phongsack Manivong, and Leslie L. Roos. 2010. "Child Health and Young Adult Outcomes." Journal of Human Resources, 45(3): 517-548.

Currie, Janet, Duque, Valentina, Garfinkel, Irwin, "The Great Recession and Mother's Health" Princeton University Working Paper, September 2014.

Dahl, Gordon B., and Lance Lochner. 2012. "The Impact of Family Income on Child Achievement: Evidence from the Earned Income Tax Credit." American Economic Review, 102(5): 1927-56

Goodman-Bacon, Andrew and Leslie McGranahan, "How do EITC recipients spend their refunds?" Federal Reserve Bank of Chicago 2q/2008 Economic Perspectives, pp.17-32.

Greg, Paul, Waldfogel, Jane and Washbrook, Elizabeth, "Expenditure Patterns PostWelfare Reform in the UK: Are low-income families starting to catch up?" LSE, CASE Working Paper, May 2005.

Hoynes, Hillary, Miller, Doug, and David Simon, "Income, the Earned Income Tax Credit, and Infant Health," American Economic Journal: Economic Policy, 7(1), 2015 172-211.

Johnson, David, Parker, Jonathan, and Nicholas Souleles, "Household Expenditure and the Income Tax Rebates of 2001," American Economic Review, 96(5), 2006, pp.1589-1610.

Mayer, Susan E. 1997. What Money Can't Buy. Cambridge, Massachusetts and London: Harvard University Press.

McGranahan, Leslie and Diane Schanzenbach, "The Earned Income Tax Credit and Food Consumption Patterns," Federal Reserve Bank of Chicago Working Paper \#2013-14, 2013.

Michelmore, Katherine, The Effect of Income on Educational Attainment: Evidence from State Earned Income Tax Credit Expansions (November 18, 2013). Available at SSRN: $\underline{\text { http://ssrn.com/abstract }=2356444 \text { or }}$ http://dx.doi.org/10.2139/ssrn.2356444 
Milligan, Kevin. 2015. Canadian Tax and Credit Simulator. Database, software and documentation, version 2015-1.

Milligan, Kevin, and Mark Stabile. 2009. "Child Benefits, Maternal Employment, and Children's Health: Evidence from Canadian Child Benefit Expansions." American Economic Review: Papers and Proceedings, 99(2): 128-132.

Milligan, Kevin, and Mark Stabile. 2011. "Do Child Tax Benefits Affect the Well-Being of Children? Evidence from Canadian Child Benefit Expansions." American Economic Journal: Economic Policy, 3(3): 175-205.

Shapiro, Matthew and Joel Slemrod, “Did the 2008 Tax Rebates Stimulate Spending?" American Economic Review Papers and Proceedings, 99(2), 2009, 374-379.

Shapiro, Matthew and Joel Slemrod, "Did the 2001 Tax Rebate Stimulate Spending? Evidence from Taxpayer Surveys," Tax Policy and the Economy, 17, pp. 83-110.

Souleles, Nicholas, "The Response of Household Consumption to Income Tax Refunds," American Economic Review, 89(4), 1999, pp.947-958.

Yang, Tzu-Ting, "Family Labor Supply and the Timing of Cash Transfers: Evidence from the Earned Income Tax Credit," University of British Columbia Working Paper, 2014.

Yeung, W. Jean, Miriam R. Linver, and Jeanne Brooks-Gunn. 2002. "How Money Matters for Young Children's Development: Parental Investment and Family Processes," Child Development, 73(6): 1861-1879. 


\section{Figures}

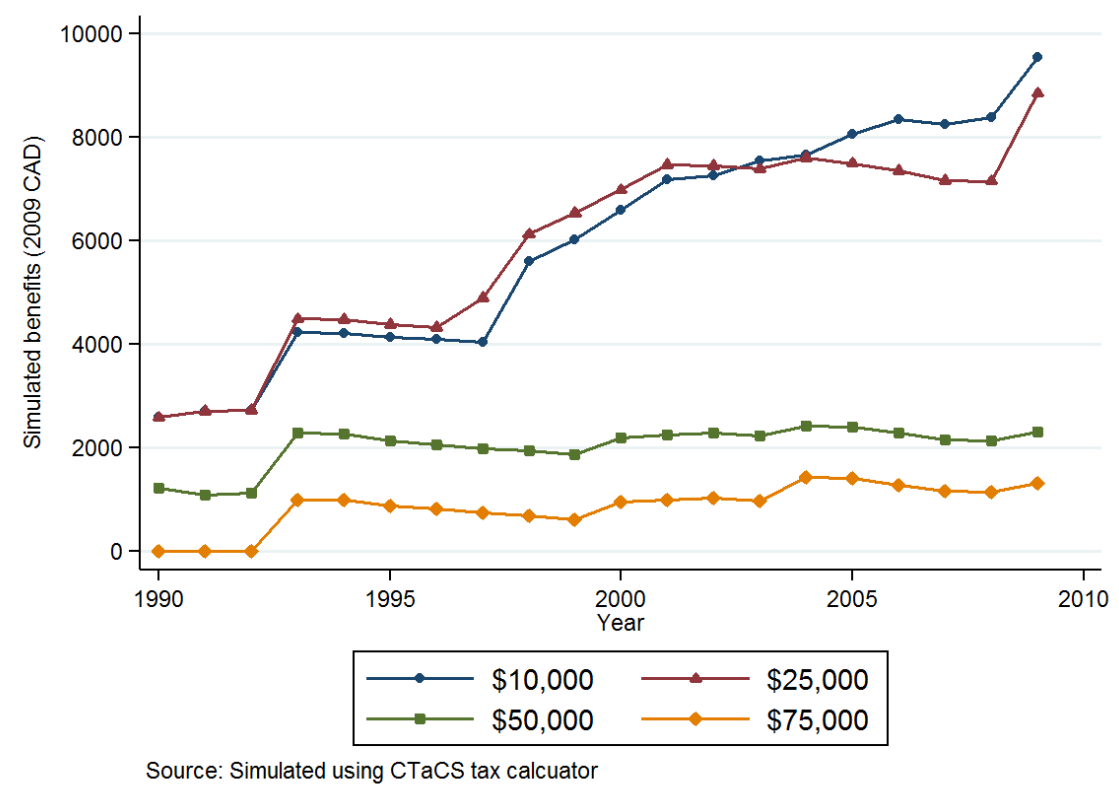

Figure 1a: Total benefits for an Ontario family with two children by income over time

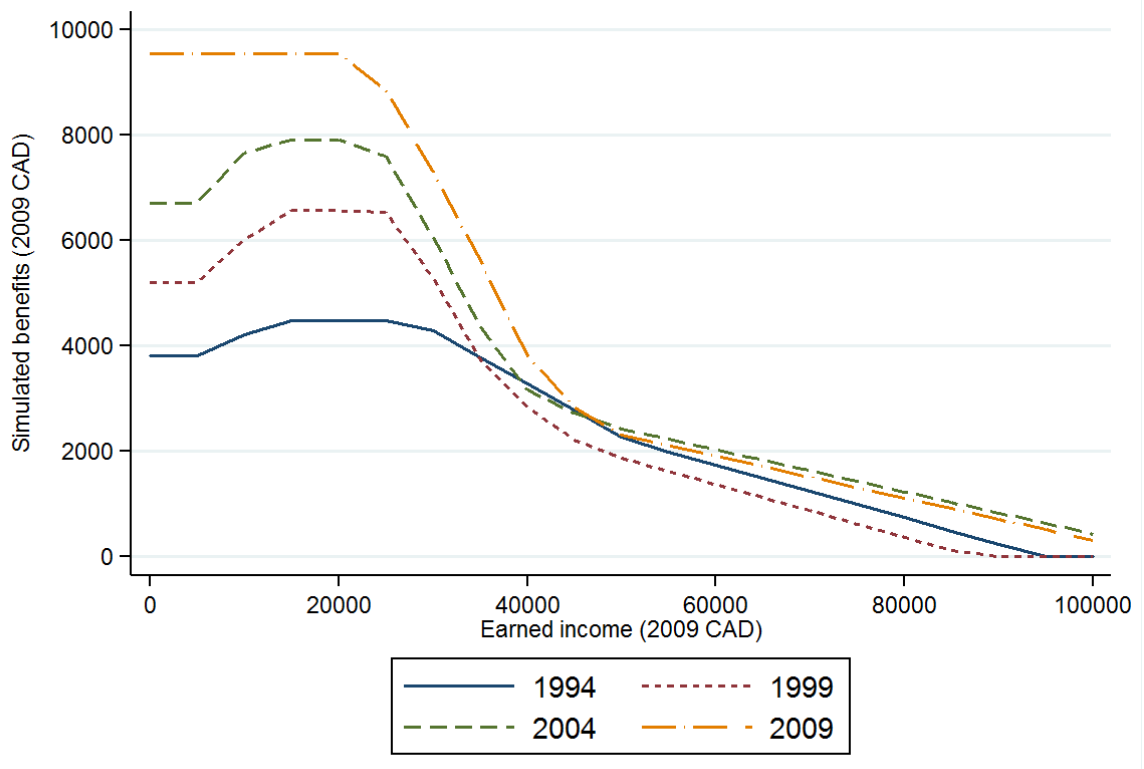

Figure 1b: Total benefits for an Ontario family with two children by year over income 


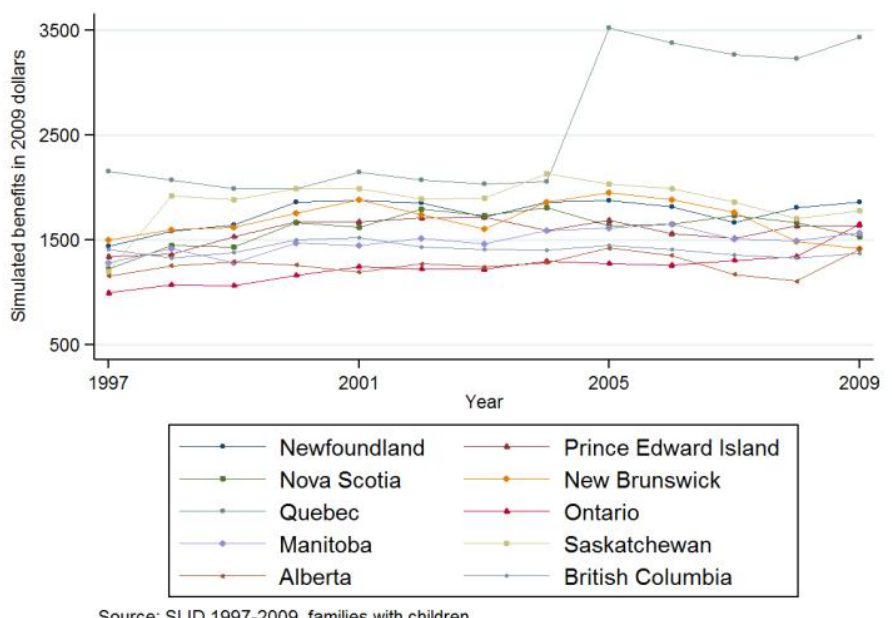

\section{One-child families}

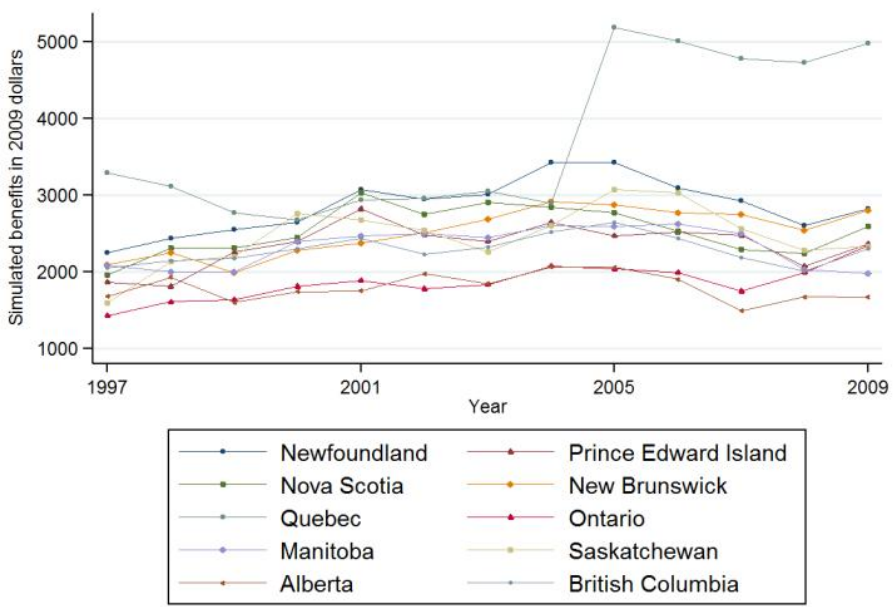

Source: SLID 1997-2009, families with children

\section{Two-child families}

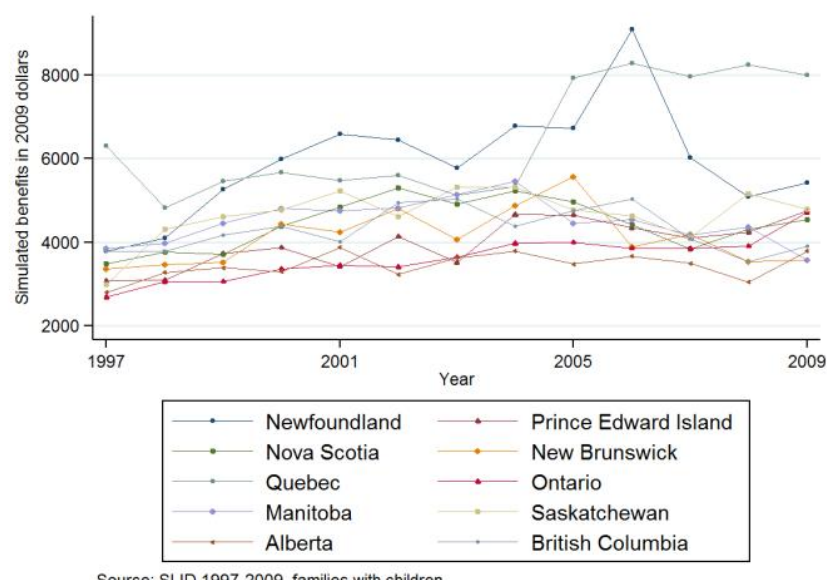

Three-child families

Figure 2. Total refundable benefits by province over time 


\section{Appendix: Child Benefits in Canada}

\section{Federal:}

The Canada Child Tax Benefit pays \$1,446 per child in 2014-15. For family net income over $\$ 43,953$ it is phased out at a rate of $2 \%$ for one child; $4 \%$ when there are two or more children. The benefit amounts and thresholds have been updated annually since 1997 for inflation, but otherwise not changed.

The National Child Benefit Supplement began in 1998. The rates for 2014-15 are $\$ 2,241$ for the first child, $\$ 1,982$ for the second, and $\$ 1,886$ for the third. The benefits are phased out sharply at rates of $12.2 \%, 23.0 \%$, and $33.3 \%$ for incomes over $\$ 25,584$. It is indexed annually for inflation. There were substantial additional increases in several years. Between 1998 and 2001 the benefit levels more than doubled. There were also increases of $13 \%$ in 2003, 14\% in 2005, and 13\% in 2006.

In 2006, the Universal Child Care Benefit was introduced. It pays $\$ 100$ per month for each child under age 6 and is taxable in the hands of the lower income spouse.

In 1997, there was a small benefit of $\$ 500$ called the Working Income Tax Benefit paid to families with children. It was phased in with income over $\$ 3,750$ and then phased out for income over $\$ 20,921$. It was removed when the National Child Benefit Supplement was introduced in 1998.

In 2007, the Working Income Tax Benefit began payments to adults. There was no supplement for children in this benefit. The amount for singles in 2014 is $\$ 998$, with couples getting $\$ 1813$. There are some differences across provinces, but for most provinces it is phased in at $25 \%$ for income over $\$ 3,000$, and phased out at $15 \%$ starting at $\$ 11,332$ for singles and $\$ 15,649$ for couples. For singles, it is completely phased out by $\$ 18,000$ - so this benefit is very narrowly targeted.

\section{Newfoundland and Labrador:}

The Newfoundland Child Benefit was introduced in 1999. In 2014, the annual rate for a first child was $\$ 369, \$ 392$, for a second child, $\$ 421$ for a third child, and $\$ 451$ for a fourth child. The clawback of these benefits was in the income range $\$ 17,397$ to $\$ 21,480$. Increases through time followed inflation, except for a $25 \%$ increase to the one-child rate in 2007. An additional supplement for children age zero was added in 2001.

\section{Prince Edward Island:}

No child benefit program.

\section{Nova Scotia:}

The Nova Scotia Child Benefit started in 1998. Families with 1 to 3 children receive different payments. Initially in 1998 , the payments ranged from $\$ 250$ for the first 
child to $\$ 136$ for a third (or higher) child. In 2001, the payments for third and higher children increased substantially. In 2005 , the payment rates were $\$ 445$ annually for a first child, $\$ 645$ for a second, and $\$ 720$ for a third. These benefits are clawed back at high clawback rates for incomes over $\$ 16,000$. Nova Scotia does not update the benefit for inflation.

In 2010, the Affordable Living Tax Credit was introduced with a base benefit of $\$ 240$ augmented by $\$ 57$ per child. This is phased out at $5 \%$ for income over $\$ 30,000$.

\section{New Brunswick:}

The New Brunswick Child Tax Benefit was introduced in 1997, before the national NCB program reached its starting point. The benefit is $\$ 250$ per child annually, and has not changed since 1997 . The benefit is clawed back at $2.5 \%$ or $5 \%$ for family net income over $\$ 20,000$. In addition, there is a Working Income Supplement of $\$ 250$ annually that is phased in at $4 \%$ for earned income over $\$ 3,750$ and clawed back at a rate of $5 \%$ for family net income over $\$ 20,921$. These amounts have been the same since 1997 with no updates for inflation.

Quebec:

Until 1997, residents of Quebec were eligible for a family allowance, an allowance for young children, and an allowance for newborn children. These amounts increased with the number of children in the family and did not depend on family income.

In 1997, these were combined into a new family allowance. The rates for the new family allowance were $\$ 2,275$ per child for a single parent family and $\$ 975$ per child for a two-parent family. These amounts were clawed back starting at incomes of $\$ 15,332$ for singles and $\$ 21,825$ for two-parent families. However, the clawback only took benefits down to a minimum benefit level that was $\$ 80$ annually for one and two child families and $\$ 975$ for three child families. But, for those with family net incomes higher than $\$ 50,000$ these 'minimum' benefits were clawed back at a rate of 5\%. In Quebec there was also an earned income benefit called APPORT in place from 1988 to 2004. In 2004, this benefit was phased in for earnings over $\$ 1,200$ at a rate of $35 \%$ until an earnings level of $\$ 11,370$ (two-parent) or $\$ 7,790$ (one-parent), and then clawed back at $43 \%$ after that. At the peak benefit level the benefit amount was quite large, but take-up of this benefit was not high.

In 2005 a new Child Assistance program replaced the family allowance. The Child Assistance benefit in 2014 was $\$ 2,341$ for the first child, $\$ 1,170$ for the second and third children, and $\$ 1,755$ for the fourth or higher child. The phaseout rate is $4 \%$ for incomes over $\$ 33,944$ (single) or $\$ 46,699$ (couple). The amounts have been updated annually for inflation.

Also in 2005, a new Work Premium replaced APPORT. It is phased in for incomes over $\$ 2,400$ (single) or $\$ 3,600$ (couple) at $25 \%$ (couples) and 30\% (single). After a 
'turnaround' point, it is phased out at a rate of $10 \%$. The turnaround point is $\$ 10,286$ (singles) or $\$ 15,914$ (couples).

\section{Ontario:}

Ontario introduced the Ontario Child Care Supplement for Working Parents in 1997. The initial rates were $\$ 400$ per child age 0 to 6 , clawed back at $4 \%$ for net family income over $\$ 20,000$. In 1998 , the amounts were revamped and largely stayed the same until 2005. From 1998, the amount was phased in with earned income over $\$ 5000$, at a rate of $20 \%$ for 1998 and $21 \%$ from 1999 to 2005 . The 2014 benefit amount was $\$ 1,100$ per child age 0 to 6 for a one-parent family and $\$ 1310$ for a twoparent family. The clawback rate was $8 \%$ for incomes over $\$ 20,000$. These amounts did not change between 1999 and 2014, with no adjustments for inflation.

In 2010, a new Sales Tax Credit was introduced, paying $\$ 260$ per member of the family; phased out with income over $\$ 25,000$ at a rate of $4 \%$.

\section{Manitoba:}

Manitoba ran its own child benefit program called CRISP until 2008. In 2008, CRISP paid $\$ 360$ annually per child, with a clawback rate of $2.083 \%$ for incomes over $\$ 12,384$. These amounts had not changed in nominal terms since the 1980s.

Starting in 2009, a new Manitoba Child Benefit was introduced, with a rate of $\$ 420$ per child, clawed back after income of $\$ 15,000$ at rates of $7.73 \%, 15.46 \%$, and $23.18 \%$ for families of one, two, and three or more children respectively. The amounts have not been updated for inflation.

\section{Saskatchewan:}

The Saskatchewan Child Benefit was introduced in 1998. In the first year, it paid $\$ 900$ annually to a one child family, $\$ 1,104$ for a second child, and $\$ 1,176$ for a third. It is clawed back at high rates for family net incomes over $\$ 15,921$. As the NCBS increased in the following years, the Saskatchewan Child Benefit was decreased downward dollar for dollar, so that by 2005 it paid only $\$ 7$ annually for a 2 nd child and $\$ 86$ for a third. It was cancelled in 2006 .

Additionally, there is a working income supplement in Saskatchewan. In 2005 the amount ranges from $\$ 2,385$ for a one child family to $\$ 4,293$ for a five child family. It is phased in for earnings over $\$ 1,500$ at rates between $25 \%$ and $45 \%$ and clawed back at a $20 \%$ rate for incomes over $\$ 14,640$. There is a supplement for children under age 13 that pays an extra $25 \%$ on top of the regular employment supplement. These amounts have not been updated for inflation through time.

In 2000, Saskatchewan introduced the Saskatchewan Low Income Tax Credit, paying $\$ 77$ for each adult and $\$ 55$ for each child. It was clawed back at $1 \%$ for incomes that varied with family type. The amounts increased to $\$ 100$ and $\$ 75$ in 2003 , then $\$ 216$ and $\$ 84$ in 2008 . The phased out rate was increased to $2 \%$, and all 
family types faced the same threshold of $\$ 28,335$. These amounts have been updated annually for inflation.

\begin{abstract}
Alberta:
Alberta has an employment-related child benefit. It was introduced in 1997 with a phase-in rate of $8 \%$ for earnings over $\$ 6,500$ up to a maximum of $\$ 250$ for one child and $\$ 500$ for two or more. The benefit is clawed back at a rate of $4 \%$ for incomes over $\$ 25,000$. Between 1998 and 2004, the benefit maximum was set at $\$ 500$ for one child and $\$ 1000$ for two or more children, but was otherwise similar to 1997.

The benefit changed again for the 2005 year. The new rates were $\$ 550$ for one child, $\$ 500$ for two children, $\$ 300$ for three children, and $\$ 100$ for four. These amounts were phased in at $8 \%$ for earnings over $\$ 2,760$, and then phased out on incomes of $\$ 25,000$ or more at a rate of $4 \%$. These amounts have been updated for inflation each year since 2005 .
\end{abstract}

\title{
British Columbia:
}

The BC Family Bonus was introduced in 1996, two years before the NCB program. The Bonus rate was $\$ 1,236$ per child and was clawed back at a rate of $8 \%$ for one child and $16 \%$ for two or more for incomes higher than $\$ 18,000$. These amounts were increased to $\$ 1,332,9 \%, 18 \%$, and $\$ 20,500$ in 2001 and have remained constant since. However, the NCBS is subtracted from the BC Family Bonus, rendering it to zero by 2005 since the NCBS is now larger than the prescribed BC Family Bonus payments.

There is also a BC Earned Income Benefit that was introduced in 1998. It pays differing amounts for each child and is phased in between earnings levels of $\$ 3,750$ and $\$ 10,000$. It is clawed back for incomes higher than $\$ 20,921$ at high rates. The amounts for 2005 are $\$ 365$ for the first child, $\$ 370$ for the second, and $\$ 372$ for the third or higher. Until 2003, the amount for the first child was $\$ 605$, with $\$ 405$ for the second and $\$ 330$ for the third. After 2003, the BC Earned Income Benefit was diminished as the NCBS grew, leading it to zero by 2013. 


\begin{tabular}{lcc}
\hline Variable & Full sample & Low-income \\
\hline Sample Demographics & & $\$ 23,772$ \\
Pre-tax household income & $\$ 65,327$ & $(9684)$ \\
& $(40445)$ & 1.67 \\
Number of children under 25 & 1.75 & $(0.79)$ \\
& $(0.77)$ & 0.45 \\
Head of household is male & 0.72 & $(0.50)$ \\
& $(0.45)$ & 36.35 \\
Age of head of household & 38.99 & $(9.51)$ \\
& $(8.42)$ & 0.48 \\
Head of household is married & 0.79 & $(0.50)$ \\
& $(0.41)$ & \\
Benefit income & & $\sim 1$ \\
Proportion receiving benefits & & $\$ 5,002$ \\
Average yearly benefit & 0.85 & $(2727)$ \\
N & $(0.36)$ & 15,261 \\
\hline
\end{tabular}

Table 1b. Means of spending variables

\begin{tabular}{|c|c|c|c|c|}
\hline \multirow{2}{*}{$\begin{array}{l}\text { Variable } \\
\text { Spending Categories }\end{array}$} & \multicolumn{2}{|c|}{ Full sample } & \multicolumn{2}{|c|}{ Low-income } \\
\hline & $\begin{array}{c}\text { Amount } \\
\text { spent }\end{array}$ & $\begin{array}{c}\text { Some } \\
\text { spending }\end{array}$ & $\begin{array}{c}\text { Amount } \\
\text { spent }\end{array}$ & $\begin{array}{c}\text { Some } \\
\text { spending }\end{array}$ \\
\hline Total Spending & $\begin{array}{l}\$ 48,269 \\
(25363)\end{array}$ & $\sim 1$ & $\begin{array}{l}\$ 26,627 \\
(13501)\end{array}$ & $\sim 1$ \\
\hline Non-durable spending & $\begin{array}{l}\$ 23,550 \\
(11731)\end{array}$ & $\sim 1$ & $\begin{array}{c}\$ 13,879 \\
(6554)\end{array}$ & $\sim 1$ \\
\hline Education spending & & & & \\
\hline $\begin{array}{l}\text { Total education } \\
\text { Tuition, supplies, reading materials, computers }\end{array}$ & $\begin{array}{l}\$ 1,780 \\
(2912)\end{array}$ & $\sim 1$ & $\begin{array}{c}\$ 901 \\
(2025)\end{array}$ & $\sim 1$ \\
\hline Tuition & $\begin{array}{l}\$ 208 \\
(398)\end{array}$ & $\begin{array}{c}0.38 \\
(0.49)\end{array}$ & $\begin{array}{l}\$ 141 \\
(291)\end{array}$ & $\begin{array}{c}0.29 \\
(0.46)\end{array}$ \\
\hline Educational supplies & $\$ 667$ & 0.68 & $\$ 388$ & 0.63 \\
\hline Supplies, textbooks & $(2160)$ & $(0.47)$ & $(1619)$ & $(0.48)$ \\
\hline Reading material & $\$ 254$ & 0.86 & $\$ 110$ & 0.73 \\
\hline Books, magazines, newspapers & $(310)$ & $(0.34)$ & $(161)$ & $(0.45)$ \\
\hline Computers & $\$ 415$ & 0.58 & $\$ 190$ & 0.36 \\
\hline Equipment, supplies & $(843)$ & $(0.49)$ & $(534)$ & $(0.48)$ \\
\hline
\end{tabular}




\begin{tabular}{|c|c|c|c|c|}
\hline \multirow[t]{2}{*}{ Variable } & \multicolumn{2}{|c|}{ Full sample } & \multicolumn{2}{|c|}{ Low-income } \\
\hline & $\begin{array}{c}\text { Amount } \\
\text { spent }\end{array}$ & $\begin{array}{c}\text { Some } \\
\text { spending }\end{array}$ & $\begin{array}{c}\text { Amount } \\
\text { spent }\end{array}$ & $\begin{array}{c}\text { Some } \\
\text { spending }\end{array}$ \\
\hline \multicolumn{5}{|l|}{ Health spending } \\
\hline Total health & $\$ 1,534$ & 1 & $\$ 774$ & \\
\hline Practitioner services, prescription drugs, insurance & $(1670)$ & $\sim 1$ & $(1022)$ & $\sim 1$ \\
\hline \multirow[t]{2}{*}{ Dental care } & $\$ 313$ & 0.57 & $\$ 145$ & 0.39 \\
\hline & $(757)$ & $(0.50)$ & $(403)$ & $(0.49)$ \\
\hline Eye care & $\$ 180$ & 0.58 & $\$ 89$ & 0.40 \\
\hline Practitioner services, eye care goods & $(349)$ & $(0.49)$ & $(205)$ & $(0.49)$ \\
\hline \multirow[t]{2}{*}{ Prescription drugs } & $\$ 199$ & 0.69 & $\$ 172$ & 0.63 \\
\hline & $(479)$ & $(0.46)$ & $(432)$ & $(0.48)$ \\
\hline \multicolumn{5}{|l|}{ Stability spending } \\
\hline Owns a home & $\mathrm{N} / \mathrm{A}$ & $\begin{array}{c}0.72 \\
(0.45)\end{array}$ & $\mathrm{N} / \mathrm{A}$ & $\begin{array}{c}0.35 \\
(0.48)\end{array}$ \\
\hline \multirow[t]{2}{*}{ Rent } & $\$ 6,096$ & 0.29 & $\$ 5,369$ & 0.64 \\
\hline & $(3524)$ & $(0.46)$ & $(2853)$ & $(0.48)$ \\
\hline \multirow[t]{2}{*}{ Food at stores } & $\$ 6,207$ & $\sim 1$ & $\$ 4,469$ & $\sim 1$ \\
\hline & $(2900)$ & $\sim 1$ & $(2239)$ & $\sim 1$ \\
\hline \multirow[t]{2}{*}{ Food at restaurants } & $\$ 1,415$ & $\sim 1$ & $\$ 675$ & $\sim 1$ \\
\hline & $(1535)$ & $\sim 1$ & $(833)$ & $\sim 1$ \\
\hline \multirow[t]{2}{*}{ Clothing } & $\$ 2,967$ & $\sim 1$ & $\$ 1,556$ & $\sim 1$ \\
\hline & $(2492)$ & $\sim 1$ & (1319) & $\sim 1$ \\
\hline \multirow{2}{*}{$\begin{array}{l}\text { Personal care } \\
\text { Toiletries, hair grooming, cosmetics }\end{array}$} & $\$ 1,085$ & $\sim 1$ & $\$ 666$ & $\sim 1$ \\
\hline & $(859)$ & & $(560)$ & $\sim 1$ \\
\hline Transportation & $\$ 2,797$ & & $\$ 1,442$ & $\sim 1$ \\
\hline Fuel, parking, public transport & $(2310)$ & & $(1496)$ & \\
\hline \multirow[t]{2}{*}{ Child care } & $\$ 917$ & 0.38 & $\$ 414$ & 0.31 \\
\hline & (2091) & $(0.49)$ & $(1053)$ & $(0.46)$ \\
\hline \multirow{2}{*}{$\begin{array}{l}\text { Recreation } \\
\text { All recreation, excluding recreational vehicles }\end{array}$} & $\$ 3,522$ & $\sim 1$ & $\$ 1,680$ & $\sim 1$ \\
\hline & (3079) & & (1493) & \\
\hline \multicolumn{5}{|l|}{ Risky spending } \\
\hline Alcohol & $\$ 615$ & 0.82 & $\$ 278$ & 0.64 \\
\hline \multirow{2}{*}{$\begin{array}{l}\text { At stores and licensed establishments } \\
\text { Tobacco }\end{array}$} & (959) & $(0.39)$ & $(573)$ & $(0.48)$ \\
\hline & $\$ 710$ & 0.45 & $\$ 675$ & 0.54 \\
\hline Cigarettes, other tobacco products & $(1286)$ & $(0.50)$ & $(1070)$ & $(0.50)$ \\
\hline $\mathrm{N}$ & & & & \\
\hline
\end{tabular}




\begin{tabular}{|c|c|c|}
\hline \multicolumn{3}{|c|}{ Panel A: SLID } \\
\hline & $\begin{array}{l}\text { Reported Child } \\
\text { Benefits }\end{array}$ & $\begin{array}{c}\text { Imputed Refundable } \\
\text { Benefits }\end{array}$ \\
\hline $\begin{array}{l}\text { Proportion of families with } \\
\text { child under } 18 \text { receiving } \\
\text { benefits }\end{array}$ & $0.81(0.39)$ & $0.80(0.40)$ \\
\hline $\begin{array}{l}\text { Average yearly benefit among } \\
\text { receivers }\end{array}$ & $\$ 2,437(2438)$ & $\$ 2,826(2819)$ \\
\hline Bottom 25 percentile & $\$ 4,071(2402)$ & $\$ 5,015(2121)$ \\
\hline \multicolumn{3}{|c|}{ Panel B: SHS } \\
\hline & $\begin{array}{l}\text { Reported Child } \\
\text { Benefits }\end{array}$ & $\begin{array}{l}\text { Imputed Refundable } \\
\text { Benefits }\end{array}$ \\
\hline $\begin{array}{l}\text { Proportion of families with } \\
\text { child under } 18 \text { receiving } \\
\text { benefits }\end{array}$ & --- & $0.85(0.36)$ \\
\hline $\begin{array}{l}\text { Average yearly benefit among } \\
\text { receivers }\end{array}$ & --- & $\$ 2,713(2563)$ \\
\hline Bottom 25 percentile & --- & $\$ 5,040(2725)$ \\
\hline
\end{tabular}

Table 3. First stage results

\section{Source of variation} Observations Province-Year Number of Children

Sample

Full sample

59,793

Low-income sample
(1)

(2)

Province - Year -

$0.826^{* * *}$

(0.039)

$0.975^{* * *}$

$\mathrm{t}=21.01$

$0.849^{* * *}$

$1.347^{* * *}$

(0.049)

(0.099)

$\mathrm{t}=17.18$

\footnotetext{
$* \mathrm{p}<0.05 ; * * \mathrm{p}<0.01 ; * * * \mathrm{p}<0.001$

Notes: Regressions using the Survey of Household Spending and instruments simulated from the Survey of Labour and Income Dynamics. Data from years 1997-2009. Regressors include gender, age and marital status of primary respondent, survey year, province and number of children dummies. Column 2 includes all first-order interactions of the year, province and number of children controls. Robust standard errors clustered at the province level reported in parentheses.
} 
Table 4. Results for total expenditures and expenditures on non-durable goods

\begin{tabular}{|c|c|c|c|}
\hline \multicolumn{4}{|c|}{ Panel A: Full Sample } \\
\hline Spending Category & Variable Mean & $\begin{array}{c}\text { (1) } \\
\text { OLS estimate } \\
\end{array}$ & $\begin{array}{c}\text { (2) } \\
\text { IV estimate }\end{array}$ \\
\hline Total expenditures & $\begin{array}{l}\$ 48,269 \\
(25363)\end{array}$ & $\begin{array}{c}-5.102^{* * *} \\
(0.429)\end{array}$ & $\begin{array}{c}-0.290 \\
(0.411)\end{array}$ \\
\hline Non-durable goods & $\begin{array}{l}\$ 23,550 \\
(11731)\end{array}$ & $\begin{array}{c}-2.236^{* * *} \\
(0.178)\end{array}$ & $\begin{array}{c}-0.077 \\
(0.195)\end{array}$ \\
\hline $\mathrm{N}$ & & 59,793 & 59,793 \\
\hline \multicolumn{4}{|c|}{ Panel B: Low-income Sample } \\
\hline Spending Category & Variable Mean & $\begin{array}{c}\text { (1) } \\
\text { OLS estimate } \\
\end{array}$ & $\begin{array}{c}\text { (2) } \\
\text { IV estimate }\end{array}$ \\
\hline Total expenditures & $\begin{array}{l}\$ 26,627 \\
(13501)\end{array}$ & $\begin{array}{c}-1.474^{* * *} \\
(0.261)\end{array}$ & $\begin{array}{c}0.376 \\
(0.253)\end{array}$ \\
\hline Non-durable goods & $\begin{array}{c}\$ 13,879 \\
(6554)\end{array}$ & $\begin{array}{c}-0.530 * * * \\
(0.107)\end{array}$ & $\begin{array}{c}0.446^{* * *} \\
(0.086)\end{array}$ \\
\hline $\mathrm{N}$ & & 15,261 & 15,261 \\
\hline
\end{tabular}

${ }^{*} \mathrm{p}<0.05 ;{ }^{* *} \mathrm{p}<0.01 ;{ }^{* * *} \mathrm{p}<0.001$

Notes: Regressions using the Survey of Household Spending and instruments simulated from the Survey of Labour and Income Dynamics. Data from years 1997-2009. Regressors include gender, age and marital status of primary respondent, survey year, province, number of children dummies, and all secondorder interactions of the year, province and number of children controls. Column (1) reports estimates from OLS models of the imputed benefit coefficients. Column (2) reports results where the SLID simulated benefits have been used as instruments from the imputed benefit amount. Robust standard errors clustered at the province level reported in parentheses. 
Table 5. Results for education and health spending categories

\begin{tabular}{|c|c|c|c|c|c|c|}
\hline \multirow[b]{2}{*}{ Spending Category } & \multicolumn{3}{|c|}{ Full Sample } & \multicolumn{3}{|c|}{ Low-income Sample } \\
\hline & Mean & $\begin{array}{c}\text { (1) } \\
\text { IV-Some } \\
\text { spending } \\
\end{array}$ & $\begin{array}{c}\text { (2) } \\
\text { IV-Total } \\
\text { spending }\end{array}$ & Mean & $\begin{array}{c}\text { (3) } \\
\text { IV-Some } \\
\text { spending }\end{array}$ & $\begin{array}{c}\text { (4) } \\
\text { IV-Total } \\
\text { spending }\end{array}$ \\
\hline \multicolumn{7}{|l|}{ Education } \\
\hline Total education & $\begin{array}{l}\$ 1,780 \\
(2912)\end{array}$ & NA & $\begin{array}{c}0.030 \\
(0.056)\end{array}$ & $\begin{array}{c}\$ 901 \\
(2025)\end{array}$ & NA & $\begin{array}{c}0.126^{* * *} \\
(0.037)\end{array}$ \\
\hline Tuition & $\begin{array}{l}\$ 208 \\
(398)\end{array}$ & $\begin{array}{c}0.023 * \\
(0.011)\end{array}$ & $\begin{array}{c}0.009 \\
(0.049)\end{array}$ & $\begin{array}{l}\$ 141 \\
(291)\end{array}$ & $\begin{array}{c}0.029 * \\
(0.013)\end{array}$ & $\begin{array}{l}0.060^{* *} \\
(0.023)\end{array}$ \\
\hline Educational supplies & $\begin{array}{c}\$ 667 \\
(2160)\end{array}$ & $\begin{array}{c}0.028^{* * *} \\
(0.006)\end{array}$ & $\begin{array}{c}-0.003 \\
(0.007)\end{array}$ & $\begin{array}{c}\$ 388 \\
(1619)\end{array}$ & $\begin{array}{c}0.013 \\
(0.007)\end{array}$ & $\begin{array}{c}-0.001 \\
(0.005)\end{array}$ \\
\hline Reading material & $\begin{array}{l}\$ 254 \\
(310)\end{array}$ & $\begin{array}{c}0.010 \\
(0.005)\end{array}$ & $\begin{array}{c}-0.005 \\
(0.009)\end{array}$ & $\begin{array}{l}\$ 110 \\
(161)\end{array}$ & $\begin{array}{c}0.011 \\
(0.009)\end{array}$ & $\begin{array}{c}0.008 \\
(0.007)\end{array}$ \\
\hline Computers & $\begin{array}{l}\$ 415 \\
(843)\end{array}$ & $\begin{array}{c}-0.013 \\
(0.014)\end{array}$ & $\begin{array}{c}0.003 \\
(0.018)\end{array}$ & $\begin{array}{l}\$ 190 \\
(534)\end{array}$ & $\begin{array}{c}0.039 * * * \\
(0.008)\end{array}$ & $\begin{array}{c}0.064^{* * *} \\
(0.018)\end{array}$ \\
\hline \multicolumn{7}{|l|}{ Health } \\
\hline Total health & $\begin{array}{l}\$ 1,534 \\
(1670)\end{array}$ & NA & $\begin{array}{c}-0.055 \\
(0.043)\end{array}$ & $\begin{array}{c}\$ 774 \\
(1022)\end{array}$ & NA & $\begin{array}{c}-0.013 \\
(0.036)\end{array}$ \\
\hline Dental care & $\begin{array}{l}\$ 313 \\
(757)\end{array}$ & $\begin{array}{c}-0.009 \\
(0.005)\end{array}$ & $\begin{array}{c}-0.057^{* *} \\
(0.022)\end{array}$ & $\begin{array}{l}\$ 145 \\
(403)\end{array}$ & $\begin{array}{c}-0.013 \\
(0.011)\end{array}$ & $\begin{array}{l}-0.019 * \\
(0.009)\end{array}$ \\
\hline Eye care & $\begin{array}{l}\$ 180 \\
(349)\end{array}$ & $\begin{array}{c}0.034^{* * *} \\
(0.004)\end{array}$ & $\begin{array}{c}0.028^{*} \\
(0.011)\end{array}$ & $\begin{array}{c}\$ 89 \\
(205)\end{array}$ & $\begin{array}{c}-0.008 \\
(0.008)\end{array}$ & $\begin{array}{c}0.001 \\
(0.007)\end{array}$ \\
\hline Prescription drugs & $\begin{array}{l}\$ 199 \\
(479)\end{array}$ & $\begin{array}{c}0.021^{*} \\
(0.011)\end{array}$ & $\begin{array}{c}-0.018 \\
(0.013)\end{array}$ & $\begin{array}{l}\$ 172 \\
(432)\end{array}$ & $\begin{array}{c}0.038 \\
(0.023)\end{array}$ & $\begin{array}{c}-0.004 \\
(0.011)\end{array}$ \\
\hline $\mathrm{N}$ & & 59,793 & & & 15,261 & \\
\hline
\end{tabular}

Notes: ${ }^{*} \mathrm{p}<0.05 ; * * \mathrm{p}<0.01 ; * * * \mathrm{p}<0.001$.

Notes: See Table 4. Columns (1) and (3) report the coefficient estimates for models of binary indicators of some spending in the given category. We do not report results for categories where approximately all respondents report having some spending. Columns (2) and (4) report the coefficient estimates for models predicting total spending in the given category. 


\begin{tabular}{|c|c|c|c|c|c|c|}
\hline \multirow[b]{2}{*}{ Spending Category } & \multicolumn{3}{|c|}{ Full Sample } & \multicolumn{3}{|c|}{ Low-income Sample } \\
\hline & Mean & $\begin{array}{c}\text { (1) } \\
\text { IV-Some } \\
\text { spending } \\
\end{array}$ & $\begin{array}{c}\text { (2) } \\
\text { IV-Total } \\
\text { spending }\end{array}$ & Mean & $\begin{array}{c}\text { (3) } \\
\text { IV-Some } \\
\text { spending }\end{array}$ & $\begin{array}{c}\text { (4) } \\
\text { IV-Total } \\
\text { spending }\end{array}$ \\
\hline \multicolumn{7}{|l|}{ Stability } \\
\hline Owns a home & $\begin{array}{c}0.72 \\
(0.45)\end{array}$ & $\begin{array}{c}-0.0000171 \\
(0.00000912)\end{array}$ & NA & $\begin{array}{c}0.35 \\
(0.48)\end{array}$ & $\begin{array}{c}0.0000282 \\
(0.0000186)\end{array}$ & NA \\
\hline Rent (among renters) & $\begin{array}{l}\$ 6,096 \\
(3524)\end{array}$ & $\begin{array}{c}0.020^{* * *} \\
(0.006)\end{array}$ & $\begin{array}{l}0.171^{*} \\
(0.085)\end{array}$ & $\begin{array}{l}\$ 5,369 \\
(2853)\end{array}$ & $\begin{array}{c}0.004 \\
(0.009)\end{array}$ & $\begin{array}{c}0.147 \\
(0.103)\end{array}$ \\
\hline Child care & $\begin{array}{c}\$ 917 \\
(2091)\end{array}$ & $\begin{array}{c}-0.038^{* * *} \\
(0.006)\end{array}$ & $\begin{array}{c}-0.027 \\
(0.033)\end{array}$ & $\begin{array}{c}\$ 414 \\
(1053)\end{array}$ & $\begin{array}{c}-0.039 * * \\
(0.014)\end{array}$ & $\begin{array}{c}0.067^{*} \\
(0.027)\end{array}$ \\
\hline Food at stores & $\begin{array}{l}\$ 6,207 \\
(2900)\end{array}$ & NA & $\begin{array}{c}0.081^{*} \\
(0.039)\end{array}$ & $\begin{array}{l}\$ 4,469 \\
(2239)\end{array}$ & NA & $\begin{array}{c}0.230 * * * \\
(0.035)\end{array}$ \\
\hline Food at restaurants & $\begin{array}{l}\$ 1,415 \\
(1535)\end{array}$ & NA & $\begin{array}{c}-0.045 \\
(0.028)\end{array}$ & $\begin{array}{l}\$ 675 \\
(833)\end{array}$ & NA & $\begin{array}{c}-0.053^{* * *} \\
(0.014)\end{array}$ \\
\hline Clothing & $\begin{array}{l}\$ 2,967 \\
(2492)\end{array}$ & NA & $\begin{array}{c}0.008 \\
(0.050)\end{array}$ & $\begin{array}{l}\$ 1,556 \\
(1319)\end{array}$ & NA & $\begin{array}{c}0.043 \\
(0.042)\end{array}$ \\
\hline Personal care & $\begin{array}{c}\$ 1,085 \\
(859)\end{array}$ & NA & $\begin{array}{c}-0.011 \\
(0.016)\end{array}$ & $\begin{array}{l}\$ 666 \\
(560)\end{array}$ & NA & $\begin{array}{c}-0.035^{* *} \\
(0.011)\end{array}$ \\
\hline Transportation & $\begin{array}{l}\$ 2,797 \\
(2310)\end{array}$ & NA & $\begin{array}{c}0.022 \\
(0.036)\end{array}$ & $\begin{array}{l}\$ 1,442 \\
(1496)\end{array}$ & NA & $\begin{array}{l}0.065^{* *} \\
(0.025)\end{array}$ \\
\hline Recreation & $\begin{array}{l}\$ 3,522 \\
(3079)\end{array}$ & NA & $\begin{array}{c}-0.050 \\
(0.060)\end{array}$ & $\begin{array}{l}\$ 1,680 \\
(1493)\end{array}$ & NA & $\begin{array}{l}0.117^{* *} \\
(0.041)\end{array}$ \\
\hline $\mathrm{N}$ & & 59,793 & & & 15,261 & \\
\hline
\end{tabular}

Notes: ${ }^{*} \mathrm{p}<0.05 ;{ }^{* *} \mathrm{p}<0.01 ;{ }^{* * *} \mathrm{p}<0.001$.

Notes: See Table 4. Columns (1) and (3) report the coefficient estimates for models of binary indicators of some spending in the given category. We do not report results for categories where approximately all respondents report having some spending. Columns (2) and (4) report the coefficient estimates for models predicting total spending in the given category. 
Table 7. Results for risky spending category

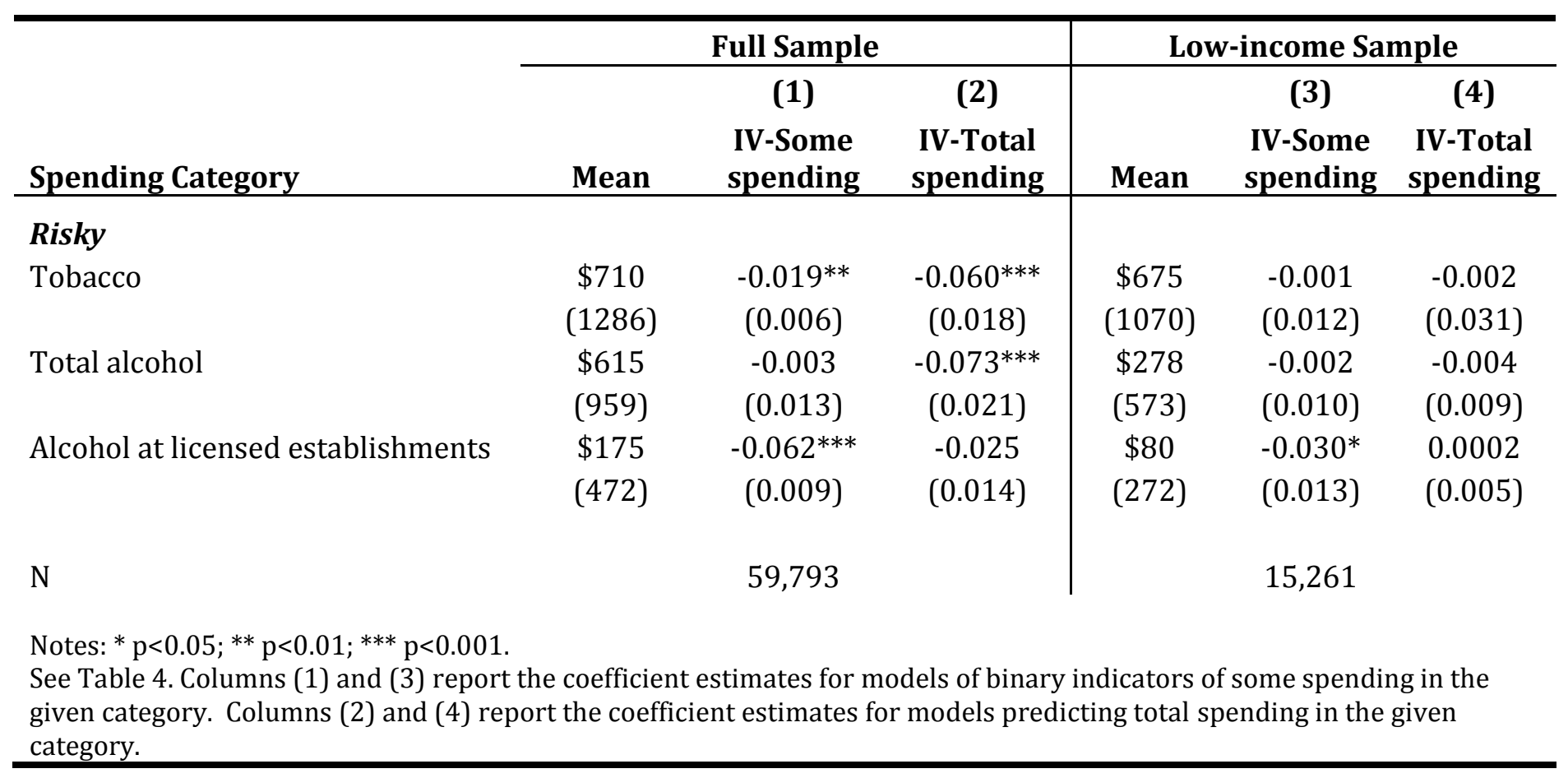

